\title{
Analysis of Causes Which Make Young People Quit Sports and Sport Activities
}

\author{
Milenko Vojvodić ${ }^{1}$, Slobodan Simović ${ }^{1 *}$, Darko Paspalj ${ }^{2}$ \\ ${ }^{1}$ University of Banja Luka, Faculty of Physical Education and Sport, the Republic of Srpska, Bosnia and Herzegovina \\ ${ }^{2}$ University of Banja Luka, Faculty of Security Sciences, the Republic of Srpska, Bosnia and Herzegovina
}

\begin{abstract}
DOI: $10.36348 /$ jaspe.2020.v03i09.001
| Received: 16.09.2020 | Accepted: 24.09.2020 | Published: 25.09 .2020
\end{abstract}

*Corresponding author: Slobodan Simović

\section{Abstract}

The research included 116 subjects who have declared that they had participated in sports, sport activities and recreation. It is a targeted sample, competent to declare their views on questions of why they practice sports and sport activities and what are the reasons (causes) for young people to quit the sport which they participated in. The results obtained on reasons for participation in sports and sport activities show that good physical shape is the primary reason, followed by health, social interaction, and friendship and making acquaintances, while a sporting career and financial benefit are by far lowest on the scale. When it comes to reasons why young people quit sports and sport activities, the majority quit because of indolence, followed by injuries, social circles, and lack of free time, pressure from overambitious parents, poor attitude of the coach, excessive exertion, and ultimately, lack of talent. When it comes to differences between attitudes on quitting sports between the sexes, occupations, smokers/non-smokers, alcohol consumers/non-consumers, and types of residential areas, the results have shown that neither the subject's sex nor alcohol consumption have an impact on attitudes on reasons for quitting sports. Some difference was observed in level of education (high school or university student), smoking (smokers or non-smokers), and type of residential area (city, suburbs, countryside).

Keywords: quitting, young, reasons, attitudes, sports, sport activities.

Copyright @ 2020: This is an open-access article distributed under the terms of the Creative Commons Attribution license which permits unrestricted use, distribution, and reproduction in any medium for non-commercial use (NonCommercial, or CC-BY-NC) provided the original author and source are credited.

\section{INTRODUCTION}

It is well known that physical activity has a positive impact on the improvement of motoric skills, the morphology and aesthetics of the body, reduces blood cholesterol levels and blood pressure, dampens the consequences of diabetes and regulates body weight, helps prevent and lessens existing deformities of the spinal column and movement apparatus, etc. [14]. In addition, there are numerous direct psychological and sociological benefits from participation in sports and sport activities [5-6], mainly in improved mental health, because regular exercise has a positive impact on one's mood, reduces depression, anxiety and stress, and improves one's mental capacity and self-esteem, but also making acquaintances, friendships, social interaction etc.

The list of reasons for participating in sports and sport activities is quite long, but for young people, health and good looks can be very high motivators for involvement [7]. A study on puberty and selfconfidence conducted by MSLGROUP Research says that the most significant benefits girls see in participating in sports is increased self-confidence $(62 \%)$, team spirit $(64 \%)$ and leadership skills (54\%) [8]. The success and future of any nation hinges on young generations, whose education is supposed to give them not only a substantial level of knowledge and skills, but also of physical capabilities. In achieving these physical and mental capabilities, participation in sports or physical activity is of the utmost importance [9]. Young people who regularly engage in sport activities are at a significantly higher level of mental and physical capacity, and they look and feel better [10]. The fact is that sports have become a major part of higher education as far back as early 19th century in the USA [11]. It is enough just to remember the boat races between Oxford and Cambridge with a tradition going back to 1829 [12] and between Harvard and Yale dating from 1859 [11]. Since the 1870s, the rowing races between these universities have been accompanied by other athletic competitions [13]. In early 20th century, sports were formalized in university campuses at the state universities of Michigan and Ohio with the appointment of sports directors [11]. 
Arthur Schopenhauer once said that health exceeds all external goods, so that a healthy beggar is truly happier than a sick king [14]. Unfortunately, there is a great deal of young people who have never participated in sports, nor have in any way been involved in sports and sport activities. They have their reasons for that [15]. There has been a lot of research showing that there are numerous obstacles for young people to participate in physical activity and sports [1617]. These are predominantly a lack of time, school obligations, lack of motivation, health issues, lack of friends who share interest in a particular sport activity, lack of facilities, and weather conditions [18-21].

This study focuses on those who participate in sports and sport activities, and then quit for any particular reason. Regardless of all scientifically proven positive effects which sports and sport activities bring about for a person, a large portion of young people do not participate, and of those who do, over time and for specific reasons, a vast number of them quit. One of the obstacles mentioned in the literature, which decreases motivation for participation in sports, is the wrong choice of the sport activity, because individuals are often not even aware of what leads them to choosing a particular sport [22-23]. When choosing a sport activity, people are often influenced by fads and do not listen to themselves and to their bodies, they choose activities unsystematically, uncontrolledly and without setting objectives [24]. Consequently, there is no joy in participation, leading to quitting the particular sport activity [25]. Dragan Milanović was critical of schools, which should, as he said, accommodate a young athlete, enabling him to participate in sports through a proper modality of education [26].

During adolescence, an individual undergoes psychological and physical changes, but what's more, they switch to the specialization stage in their sports training (age 13-16), and the sport is no longer a game, but rather an opportunity for development and for assuming the role of a professional athlete. It is during this stage in sports training, when top athletes develop and get focused, that a vast number of participants quit sports, which prompted the authors to explore the process of quitting sports in adolescence. Previous research has pointed out the importance of understanding quitting sports as a motivational process impacted by social factors and psychological mediators [27]. In the book Mental Training (Serbian: Mentalni trening), the author states that there are three basic reasons why young people quit sports. They are loss of interest, failure to meet one's own expectations, and a feeling of incompetence [28]. The Always Confidence \& Puberty Wave IV Study, by MSLGROUP Research, states that by the age of 17 , i.e. by the end of puberty, more than half girls (51\%) quit sports, 7 out of 10 girls who quit sports during puberty feel like they don't belong to the sport, while only a third of the girls believe that the society encourages girls to participate in sports [8]. Darrell Burnett, American psychologist and coach for young athletes, believes that positive encouragement which children receive from their coaches is a key component of the success of sports programmes for young people, and at the same time the main reason why they carry on participating [25]. A successful coach for young athletes, he points out, is not defined in terms of achieved wins and losses, but in the number of children who continue participating in sports in the following year as well [29].

In terms of anticipating the intent of young girls to keep participating in their respective sports for the next 6-12 months, only enjoyment was significant. For these girls (age 10-14), parents had the greatest influence in determining their positive psychological experiences in sports. As expected, fun/enjoyment was a key variable in relation to understanding who was going to keep participating [30].

Stefan Wagnsson, Göran Patriksson, \& Peter Carlman carried out a study to explore reasons for quitting sports in relation to demographic variables, various types of sports, physical activities and motivational processes. The results they obtained indicated that more likely to quit their sport sooner are girls of foreign origin, athletes who are less fit, as well as those lacking social skills [31].

Tak Dangi \& Peter Witt offered three sets of reasons or limitations for children and young people quitting sports. They are personal limitations, which include a lack of enjoyment, low perception of own physical capacity, internal pressure (e.g. stress) and a negative atmosphere in the club, i.e. negative feelings towards the team or the coach. Interpersonal limitations include parental pressure and loss of independence, and insufficient time to participate in other age-appropriate activities. And ultimately, structural limitations include time (training and travel), injuries, expenses and inadequate benefits [32].

Sanja Ljubičić, Ljubomir Antekolović, and Josipa Antekolovič explored why large numbers of young people quit athletics in Croatia and concluded that in the subjective opinion of the interviewees, the most common reasons for quitting were motivational, then too many obligations at school (or university or employment), and serious injury. Further, motivational factors play an important, and often a crucial role in sports [33].

What can be concluded from previous research is that participation in sports and recreation enables pupils and students to improve their physiological, social and psychological needs [34] that it brings significant benefits both during studies and after graduation [6] and that high schools and universities, as educational institutions, are important places for developing lifelong habits [35]. 
This paper aims to determine how much each of these individual reasons influences participation in sports and sport activities, and how much each of them influences quitting sports. Further, the aim is to see if there are substantial differences in the interviewees' ideas of the reasons causing participants to quit sports and sport activities between the sexes, between pupils and students, and between smokers and non-smokers. Ultimately, the aim is to see if place of residence or consumption of alcohol influences the interviewees' perception of what causes participation to quit sports and sport activities.

\section{MATERIALS AND METHODS}

The subject sample comprised 226 high school pupils and university students. A total of 110 stated that they had never participated in sports or any kind of sport activity or recreation, while 116 stated that they were in some way involved in sports and sport activities.

This paper focuses solely on the 116 subjects who have declared that they had participated in sports, sport activities and recreation. It is a targeted sample of subjects competent to comment on the topic of the paper. Otherwise, a random sample might produce less reliable and less valid answers, remarks, views etc [36].

The variable sample comprises questions regarding the subjects' sex, occupation, age, alcohol consumption, smoking, and type of residential area, as well as questions on how the subjects were involved in sports, who provided the most motivation for them to get into sports, how many times a week they trained, whether they enjoyed participating in sports, and if their parents participated in any sports. In addition, the subjects gave their comments on the degree to which these factors influenced their participation in sports and sport activities. The stated reasons were: a sporting career and future, financial benefit, good physical shape, social interaction, friendship, making acquaintances, and health. Ultimately, the subjects commented on the extent to which these reasons were responsible for young people quitting sports and sport activities they participated in. These reasons, or causes, are: poor attitude of the coach, excessive exertion, injuries, and lack of free time, lack of talent, indolence, pressure from overambitious parents, the participant's social circles.

To ascertain how much each of the individual causes, according to the interviewees, accounts for quitting sports and sport activities, the percentages and absolute frequencies have been broken down for each individual cause. To ascertain differences between viewpoints of the sexes, high school pupils and students on the causes for quitting sports and sport activities, and to ascertain whether place of residence or alcohol and cigarette consumption affect quitting sports and sport activities, the Mann-Whitney $U$ test and the KruskalWallis $\mathrm{H}$ test were used as a nonparametric alternative to the $\mathrm{T}$ test and single-factor variance analysis.

A five-point Likert scale was used to obtain the viewpoints: strongly disagree, disagree, partly agree, agree and strongly agree.

The research was conducted in line with the ethical standards of the University and Banja Luka and the applicable legislation of Bosnia and Herzegovina. When selecting the variables relating to reasons for participation in sports and reasons for quitting sports, special attention was given so they would have satisfactory reliability of the internal consistency type (Cronbach alpha $\alpha=.65$ ), to achieve the aim of the research.

\section{RESULTS}

The first three graphs (Figures 1, 2 and 3) show the frequencies and percentages of the observed phenomena. Thus, Figure 1 shows which person provided crucial motivation for the subjects to participate in sports, when they started doing sport activities and whether the subjects enjoyed participating in sports.

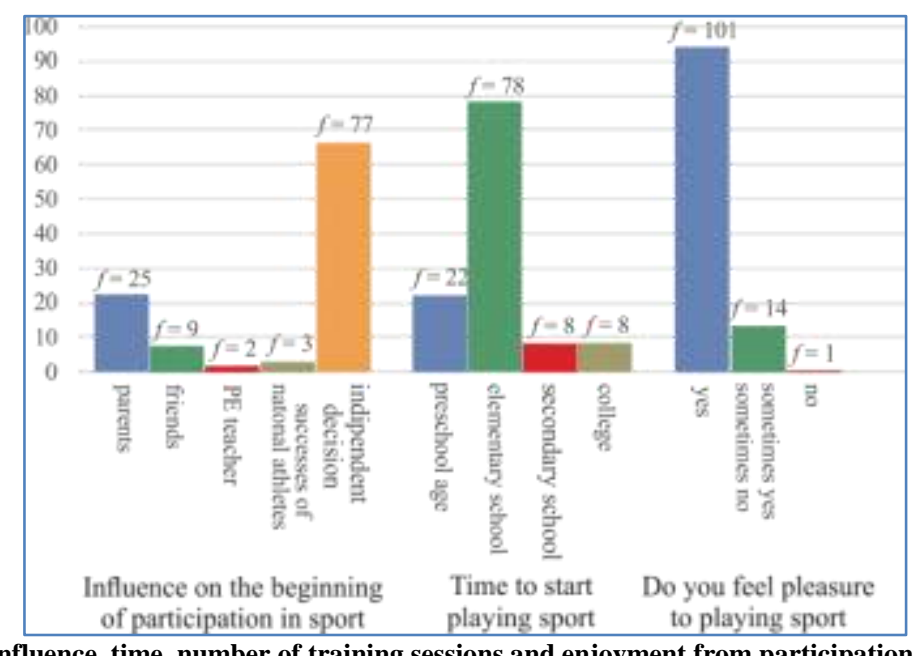

Fig-1: Influence, time, number of training sessions and enjoyment from participation in sports 
In Figure 2 we can see the reasons why the subjects participated in sports.

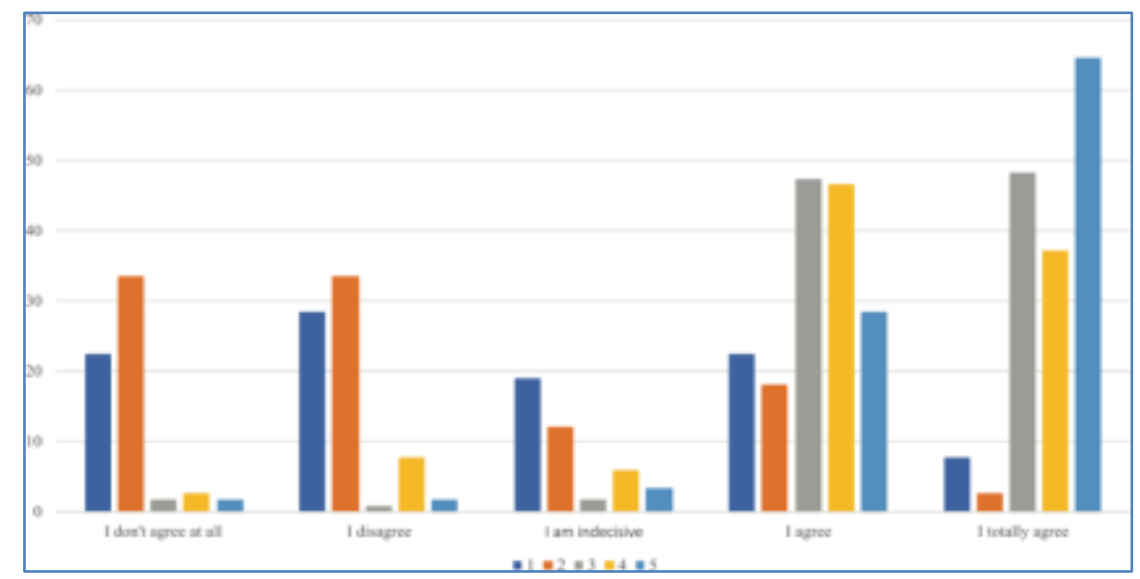

Fig-2: Reasons for participating in sports

Key: 1 - a sporting career and future, 2 - financial benefit, 3 - good physical shape, 4 - social interaction, friendship, and making acquaintances, 5 - health.

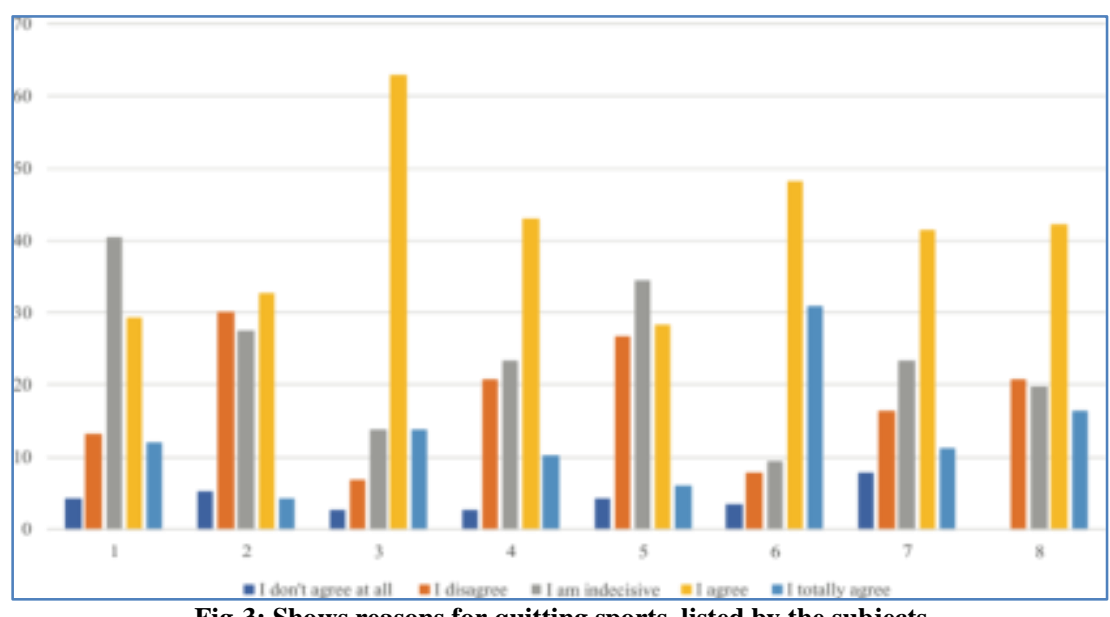

Fig-3: Shows reasons for quitting sports, listed by the subjects

Key: 1 - poor attitude of the coach, $2-$ excessive exertion, 3 - injuries, 4 - lack of free time, 5 - lack of talent, 6 - indolence, 7 - pressure from overambitious parents, 8 - the participant's social circles. Figure 3. Reasons for quitting sports
Table 1 shows the results of the MannWhitney $U$ test of differences between views of high school pupils and university students on reasons for quitting sports.

Table-1: Level of education as a source of differences in views on quitting sports

\begin{tabular}{|c|c|c|c|c|c|}
\hline & & $N$ & $M$ & Sum of Ranks & Mann-Whitney U test \\
\hline \multirow[t]{2}{*}{1} & \multirow{2}{*}{$\begin{array}{l}\text { pupil } \\
\text { student }\end{array}$} & \multirow{2}{*}{$\begin{array}{l}55 \\
61 \\
\end{array}$} & 45.93 & 2526.00 & \multirow[t]{2}{*}{.000} \\
\hline & & & 69.84 & 4260.00 & \\
\hline \multirow[t]{2}{*}{2} & \multirow{2}{*}{$\begin{array}{l}\text { pupil } \\
\text { student }\end{array}$} & 55 & 56.42 & 3103.00 & \multirow[t]{2}{*}{.508} \\
\hline & & 61 & 60.38 & 3683.00 & \\
\hline \multirow[t]{2}{*}{3} & \multirow{2}{*}{$\begin{array}{l}\text { pupil } \\
\text { student }\end{array}$} & 55 & 56.12 & 3086.50 & \multirow[t]{2}{*}{.401} \\
\hline & & 61 & 60.65 & 3699.50 & \\
\hline \multirow[t]{2}{*}{4} & \multirow{2}{*}{$\begin{array}{l}\text { pupil } \\
\text { student }\end{array}$} & 55 & 60.76 & 3342.00 & \multirow[t]{2}{*}{.467} \\
\hline & & 61 & 56.46 & 3444.00 & \\
\hline \multirow[t]{2}{*}{5} & \multirow{2}{*}{$\begin{array}{l}\text { pupil } \\
\text { student }\end{array}$} & 55 & 56.01 & 3080.50 & \multirow[t]{2}{*}{.429} \\
\hline & & 61 & 60.75 & 3705.50 & \\
\hline \multirow[t]{2}{*}{6} & \multirow{2}{*}{$\begin{array}{l}\text { pupil } \\
\text { student }\end{array}$} & 55 & 49.98 & 2749.00 & \multirow[t]{2}{*}{.005} \\
\hline & & 61 & 66.18 & 4037.00 & \\
\hline \multirow[t]{2}{*}{7} & \multirow{2}{*}{$\begin{array}{l}\text { pupil } \\
\text { student }\end{array}$} & 55 & 44.98 & 2474.00 & \multirow[t]{2}{*}{.000} \\
\hline & & 61 & 70.69 & 4312.00 & \\
\hline \multirow[t]{2}{*}{8} & \multirow{2}{*}{$\begin{array}{l}\text { pupil } \\
\text { student }\end{array}$} & 55 & 44.60 & 2453.00 & \multirow[t]{2}{*}{.000} \\
\hline & & 61 & 71.03 & 4333.00 & \\
\hline
\end{tabular}


Key: 1 - quitting the sport because of a poor attitude of the coach, 2 - quitting the sport because of excessive exertion, 3 - quitting the sport because of injuries, 4 - quitting the sport because of a lack of free time, 5 - quitting the sport because of a lack of talent, 6 - quitting the sport because of indolence, 7 - quitting the sport because of pressure from overambitious parents, $8-$ quitting the sport because of the participant's social circles

Table 2 shows the difference in views between smokers and non-smokers on reasons for quitting sports.

Table-2: Smoking as a source of differences in views on quitting sports and sport activities

\begin{tabular}{|l|c|c|c|c|c|c|c|}
\hline & $\boldsymbol{N}$ & Mean Rank & Sum of Ranks & $\mathbf{U}$ test & $\mathbf{W}$ test & $\mathbf{Z}$ & $\boldsymbol{p}$ \\
\hline smoker & 19 & 72.92 & 1385.50 & \multirow{2}{*}{647,500} & 5400.500 & $-2,158$ & $\mathbf{. 0 3 1}$ \\
\hline non-smoker & 97 & 55.68 & 5400.50 & & & & \\
\hline
\end{tabular}

Table 3 shows the difference in views on reasons why high school pupils and university students quit sports in relation to place of residence.

Table-3: Place of residence as a source of differences in views on reasons for quitting sports and sport activities

\begin{tabular}{|l|c|c|c|c|c|}
\hline & $\boldsymbol{N}$ & Mean Rank & $\boldsymbol{\chi}^{\mathbf{2}}$ & $\boldsymbol{d f}$ & $\boldsymbol{p}$ \\
\hline city & 52 & 58.88 & & & \\
\cline { 1 - 3 } suburbs & 40 & 67.54 & \multirow{2}{*}{9,119} & 2 & $\mathbf{. 0 1 0}$ \\
\hline countryside & 24 & 42.63 & & & \\
\hline
\end{tabular}

\section{DISCUSSION}

The first set of columns in Figure 1 shows who provided the most motivation for the subjects to get into sports and sport activities. The majority of the subjects (77, or $66.4 \%)$ stated that the motivation was internal. It seems that the subjects were not completely honest with this question, since the majority of them started participating in sports in pre-school years or in elementary school, which can be seen in the second set of columns, and it would make sense that, at such an age, somebody influenced their decision. Twenty-five subjects $(21.6 \%)$ stated their parents as having the most influence. The other answers include friends (9, or $7.8 \%$ ), PE teacher, and international successes of our athletes. The second set of columns shows that the majority of the subjects started participating in sports during elementary school (78, or $67.2 \%)$, followed by pre-school $(22$, or $19 \%)$, while eight of them $(6.9 \%)$ stated high school and university. The third set of columns in Figure 1 shows results for the subjects' enjoyment of participation in sports.

Analysis of the results in Figure 2 on reasons for participation in sports and sport activities shows that good physical shape is the primary reason, followed by health, social interaction, and friendship and making acquaintances, while a sporting career and financial benefit are by far lowest on the scale. A total of 111 subjects $(95.7 \%)$ agreed and strongly agreed that they participated in sports and sport activities to maintain good physical shape. Similar results were obtained in a study by Geoff Lovell, Walid El Ansari, and John Parker [3]. A close second perceived reason for participating in sports is health, for a total of 107 subjects $(93.1 \%)$, out of which $33(28.4 \%)$ agree and 74 $(64.7 \%)$ strongly agree. Health as a reason for participating in sports during education was ascertained in other studies as well [5]. Social interaction, friendship and making acquaintances is in third place as a reason for participating in sports, where 97 subjects $(83.7 \%)$ agreed and strongly agreed. This reason for participating in sports was also ascertained in other studies as well [37]. A sporting career and financial benefit are at the bottom of the scale. These results are somewhat logical, because the sample comprised 31 active athletes and 85 recreation athletes, although this reason was highly ranked in some other studies [17, 38]. A USADA study yielded data which suggests that young people who participate in sports and enjoy it, while getting additional benefits, are likely to keep doing it and choose to do it professionally. The study stated reasons why young people participate in sports, some of which are: fun, social interaction, improvement of playing skills, health, doing something useful, selfconfidence, parental influence, testing the limits of the body and mind [39].

When it comes to causes, i.e. reasons why, according to the study subjects, young people quit sports and sport activities, the results have shown (Figure 3 ) that the majority quit because of indolence, which is somewhat surprising and speaks a lot about their honesty and self-criticism. A total of 92 subjects $(79.3 \%)$ stated that they agree or strongly agree with that statement. Similar results were obtained in a study by Meral Kucuk Yetgin [40]. In second place are injuries, with 89 subjects $(76.7 \%)$ who agreed or strongly agreed, which was also confirmed, along with fatigue, in a previous study [38]. The third-placed reasons for quitting sports, according to the subjects, are the participants' social circles. A total of 68 subjects $(58.6 \%)$ agreed and strongly agreed with this statement. This reason was also confirmed in other studies as well [38]. The next reason is the lack of free time $(53.4 \%)$, which was also found in other studies, as well as excessive school obligations [41], pressure from 
overambitious parents $(52.6 \%)$, poor attitude of the coach (41.4\%), excessive exertion $(37.1 \%)$ and ultimately, lack of talent, declared by around $34.4 \%$ of the subjects. Ljubica Bačanac, Nebojša Petrović, and Nenad Manojlović found that the primary reasons for quitting sports are: loss of interest in sports, emergence of other interests, lack of enjoyment, too much time needed, poor pedagogical approach of the coach, lack of success and progress, favouritism by the coach, time needed for school obligations, too difficult training regimes, boring and monotonous training, poor organization and communication, too much emphasis on victory, small amount of minutes played, lack of parental support [42]. Suggestions for minimizing the abandonment of sports and increasing the participation of young people include redefining goals in sports from victory to fun, balancing parental involvement, encouraging participation in multiple sports, providing young people with independence and ownership of the playing experience, appealing to the parents to avoid living their sports dreams through their children [32]. It is not surprising that a lack of fun, as the primary motivator for getting involved in sports, is the main reason why young people stop participating in sports. Other reasons were that they wanted to do something else and wanted to focus more on school activities. It is interesting that $21 \%$ quit sports because they felt they were not as good as the others and $13 \%$ stated that costs were an obstacle, pointing out competitiveness, specialization and accessibility [32]. These reasons should be further explored because research indicates a low level of pupil and student participation in sports $[7$, 38]. The reasons given by the subjects in this study fit under the first two factors (intrapersonal and interpersonal) of the hierarchical model of limitations for participation in sports and recreation [43]. There is a noticeable lack of structural reasons in this study, while in other studies pupils and students have listed primarily their financial situation and access to sports facilities [3, 39, 44-45].

One of the tasks of this study was to see if views on quitting sports are influenced by the subjects' sex, level of education, smoking/non-smoking, alcohol consumption, and place of residence.

Table 1 presents the results of the MannWhitney $\mathrm{U}$ test, showing a difference in views between high school pupils and university students on reasons for quitting sports. Statistically significant differences have manifested in views on quitting because of a poor attitude of the coach $p=.00$, because of indolence $p=.00$, because of overambitious parents $p=.00$ and because of the participants' social circles $p=.00$. It is clear that for all reasons for quitting sports where there was a statistically significant difference; students confirmed their views at a higher rate. The different views of high school pupils and university students are probably a consequence of maturity, honesty and objectiveness in providing their views.
Also, the results of the Mann-Whitney U test showed that the subjects' sex does not affect differences in views on reasons for quitting sports. The largest difference was obtained in views pertaining to lack of talent, at $p=.09$, which is not a statistically significant difference. It should still be noted that males confirm their views at a higher rate that lack of talent is a reason for quitting sports.

Smokers and non-smokers (Table 2) exhibit statistically significant differences in views in only one of the listed causes - quitting sports because of a lack of free time $(p=.03)$, and when observing mean ranking values, it can be seen that smokers confirm their views at a higher rate. At first glance this may seem odd, but taking into account that the average smoker consumes 20 cigarettes a day, and that it takes them about ten minutes to smoke one cigarette, they spend almost three and a half hours a day on smoking only. And since they usually smoke in their free time, it is logical to assume that this is why they lack free time for sports and sport activities.

Just like the subjects' sex, alcohol is also not a source of differences in views on reasons for quitting sports and sport activities. In other words, the results of the Kruskal-Wallis H test showed that those who do not consume alcohol sometimes consume alcohol and do consume alcohol, do not exhibit significantly different views on quitting sports.

Looking at the results of the Kruskal-Wallis $\mathrm{H}$ test (Table 3), a significant difference can be seen at the level of $p=.01$ between pupils and students who participate in sports, living in the city, the suburbs, or the countryside. In other words, place of residence is a source of differences in views on quitting sports due to a poor attitude of the coach. Observing the mean ranking values, it can be seen that residents of suburban areas confirm their views at the highest rate on quitting sports because of poor attitude of the coach. When it comes to other reasons (causes) for quitting sports and sport activities, there is no statistically significant differences in views according to those causes between those who live in the city, the suburbs or the countryside.

\section{CONCLUSION}

There are many reasons to participate in sports and sport activities, but unfortunately also to quit. This paper presents some of the reasons why young people, according to their own views, participate in sports and sport activities, but also some reasons why they quit. Good physical shape is the top-ranked reason for participating in sports and sport activities for both pupils and students. As many as $95.7 \%$ of them agreed to that statement. A close second perceived reason for participating in sports is health, for $93.1 \%$ of the subjects. Social interaction, friendship and making acquaintances is in third place with $83.7 \%$ of the 
subjects, while a sporting career and financial benefit are at the bottom of the scale. These results are somewhat logical, because the sample comprised 31 active athletes and 85 recreation athletes.

When it comes to causes, i.e. reasons why, according to the study subjects, young people quit sports and sport activities, the results have shown that the majority quit because of indolence, which is somewhat surprising and speaks a lot about their honesty and self-criticism. In second place are injuries, and in third place, as reasons for quitting sports, according to the subjects, are the participants' social circles. The next reason is the lack of free time, pressure from overambitious parents, poor attitude of the coach, excessive exertion, and ultimately, lack of talent, declared as a reason for quitting sports by the least number of the subjects in total. It should be said that there are other reasons, mentioned by other authors: lack of enjoyment, stress, loss of self-confidence, negative atmosphere in the team, loss of independence, costs, and insufficient relief.

Another important matter is that reasons for quitting sports are not affected by the subjects' sex, nor are there differences in views among those who do not consume alcohol, occasionally consume alcohol, or consume alcohol. A difference was proven in views of high school pupils and university students, probably as a consequence of maturity, honesty and objectiveness in providing their views. Smokers and non-smokers only disagree on one reason, which is free time. One of the assumptions was that place of residence (city, suburbs, countryside) might provide for differences in views on quitting sports. The results have shown that there is a significant difference only for views pertaining to poor attitude of the coach.

\section{REFERENCES}

1. Awotidebe, T.O., Adedoyin, R.A., Adegbesan, O., A. Babalola, J.F. Olukoju, I.O., Mbada, C.E., Chirwa, E., \& Bisiriyu, L.A. (2014). Psychosocial correlates of physical activity participation among Nigerian university students. International Journal of Sports Science, 4(6), 205-211.

2. Halforty, G.A., \& Radder, L. (2015). Constraints to participation in organized sport: Case of senior undergraduate students at a new generation university. South African Journal for Research in Sport, Physical Education and Recreation, 37(3), 97-111.

3. Lovell, G., Ansari, W.E., \& Parker, J.K. (2010). Perceived exercise benefits and barriers of nonexercising female university students in the United Kingdom. International Journal of Environmental Research and Public Health, 7(3), 784-798.

4. Peltzer, K., \& Pengpid, S. (2016). Leisure time physical inactivity and sedentary behaviour and lifestyle correlates among students aged 13-15 in the Association of Southeast Asian Nations
(ASEAN) member states, 2007-2013. International journal of Environmental Research and Public Health, 13(2), 217.

5. Eben, W., \& Brudzynski, L. (2008). Motivations and barriers to exercise among college students. Journal of Exercise Physiology, 11(5), 1-11.

6. Henchy, A. (2011). The influence of campus recreation beyond the gym. Recreational Sports Journal, 35(2), 174-181.

7. Peters, N. (2014). Determining the demand for recreational sport at a university. Unpublished master thesis, North-West University, Potchefstroom, South Africa.

8. MSLGROUP. (2016). The Always Confidence\&Puberty Wave IV study. Retrived April 22, 2017, from https://news.pg.com.

9. Chiu, L.K., Yusof, M.M., Fauzee, M.S.O., Othman, A.T., Aman, M.S., Elumalai, G., \& Ali, H.M. (2016). Examining sport and physical activity participation, motivations and barriers among young Malaysians. Asian Social Science, 12(1), 159-171.

10. Masten, R., Dimec, T., Donko, A. I., \& Tusak, M. (2010). Motives for sports participation, attitudes to sport and general health status of the Slovenian armed forces employees. Kinesiology, 42(2), 153 163.

11. Mittelstaedt, R., Robertson, B., Russell, K., Byl, J., Temple, J., \& Ogilvie, L. (2013). Chapter 11, unique groups: campus recreation. In Human Kinetics (eds), Introduction to Recreation and Leisure (2nd ed, pp. 216-219). Champaign, IL: Human Kinetics.

12. Edwards, A.M., Guy, J.H., Hettinga, F.J. (2016). Oxford and Cambridge boat race: Performance, pacing, and tactics between 1890 and 2014. Sports Medicine, 46(10): 1553-1562.

13. Rice, E.A. (1929). A brief history of physical education. New York: Barnes.

14. Zivanovic, N., Randjelovic, N., Stankovic, V., \& Pavlovic, P. (2010). Theory of Physical Culture. Nis: Faculty of Sport and Physical Education University of Nis.

15. Vojvodic, M., Simovic, S., \& Paspalj, D. (2019). The reasons why young people avoid engaging in sports and athletic activities. Sports Science and Health, 9(1): 65-75.

16. Mugwedi, N.P., \& Mulibana, P.K. (2014). Constraints faced by University of Venda students in sport and recreation participation. African Journal for Physical, Health Education, Recreation and Dance, Supp. 1, 359-369.

17. Peters, N., Scholtz, E, M., \& Weilbach, J.T. (2014). Determining the demand for recreational sport at a university. Unpublished master thesis. Potchefstroom, South Africa: North-West University.

18. Buckworth, J., \& Dishman, R.K. (2002). Exercise psychology. Champaign, IL: Human Kinetics. 
19. Nolan, V.T., \& Surujlal, J. (2011). Participation in physical activity: an empirical study of undergraduate university students ${ }^{\text {ee }}$ perceptions. African Journal for Physical, Health Education, Recreation and Dance, Supp. 1, 70-85.

20. Shifman, R., Moss, K., D’Andrade, G., Eichel, J., \& Forrester, S. (2011). A comparison of constraints to participation in intramural sports between international and non-international students. Recreational Sports Journal, 36, 2-12.

21. Thatcher, J. (2009). Motivation in sport and exercise. In J. Thatcher, R. Thatcher, M. Day, A. Portas, \& S. Hood (Eds.), Sport and exercise science (pp. 67-85). Exeter: Learning Matters.

22. Peralta, M., Martins, J., Marques, A., \& Correia, C. (2013). Correlates of motivation to practice physical activity among students from Portuguese military college. British Journal of Sport Medicine, 47, 17 -e4.

23. Turkmen, M. (2013). Investigation of the relationship between academic and sport motivation orientations. Middle East Journal of Scientific Research, 16(7), 1008-1014.

24. Cerar, K., Kondric, M., Ochiana, N., \& Sindik, J. (2017). Exercise participation motives and engaging in sports activity among University of Ljubljana students. Macedonian Journal of Medical Sciences, 5(6), 794-799.

25. Fortes, P.C., Rodrigues, G., \& Tchantchane, A. (2011). Investigation of academic and athletic motivation on academic performance among university students. International Proceedings of Economics Development and Research Business and Management, 2, 181-185.

26. Milanovic, D. (2005). Training theory. Zagreb: Faculty of Kinesiology University of Zagreb.

27. Trbojevic, J. (2018). Socio-psychological predictors of giving up sports in adolescence. Unpublished PhD Dissertation. Novi Sad: Department of Psychology of Faculty of Philosophy University of Novi Sad.

28. Cerensek, I. (2017). Mental training. Retrived December 7, 2018, from https://mentalnitrening.hr/author/igor-cerensek/.

29. Burnett, D. (2003). Positive coaching: A behavior checklist for youth sports coaches. Retrived October 4, 2016, from http://www.midcitiesbasketbal.org

30. Atkins, M. R., Johnson, D. M., Force, E. C., \& Petrie, T. A. (2013). Do I still want to play? Parents' and peers' influences on girls' continuation in sport. Journal of Sport Behavior, 36, 329-345.

31. Wagnsson, S., Patriksson, G., \& Carlman, P. (2013). Causes and consequences of dropping out from organized youth sports. Swedish Journal of Sports Research, 1, 26-54.
32. Dangi, T., \& Witt, P. A. (2016). Why children/youth drop out of sports. Sequor Youth Development Initiative, 1-7.

33. Ljubicic, S., Antekolovic, L.J., \& Antekolovic, J. (2016). Reasons why young people quit athletics. Proceedings of 25th Summer School of Kinesiologists of the Republic of Croatia, 647-653.

34. World Health Organization. (2014). Global status report on non-communicable diseases. Retrieved from:

http://apps.who.int/iris/bitstream/10665/148114/1/9 789241564854_eng.pdf?ua=1

35. Smith, B.D. (2008). Motivational factors for student participation in collegiate club sports at Indiana University. Unpublished MA thesis, Indiana University, School of Health, Physical Education and Recreation.

36. Mijanovic, M., \& Vojvodic, M. (2008). Methodology of the anthropology of sport. Banja Luka: Faculty of Physical Education and Sport University of Banja Luka.

37. Hoe, W.E. (2007). Motives and constraints to physical activities participation among undergraduates. Shah Alam, Selangor, Malaysia: Universiti Teknologi MARA.

38. Kubayi, N.A., \& Surujal, J. (2014). Perceived benefits of and barriers to exercise participation among secondary school students. Mediterranean Journal of Social Sciences, 20(5), 121-126.

39. USADA. (2011). What sport means in America: A study of sport's role in society, Colorado Springs, CO: USADA.

40. Yetgin, M.K. (2014). Views of students in the School of Physical Education and Sports on leisure constraints. International Journal of Social Science and Education, 4(4), 818-828.

41. Daskapan, A., Tuzun, E.H., \& Eker, L. (2006). Perceived barriers to physical activity in university students. Journal of Sports Science and Medicine, 5(4), 615-620.

42. Bacanac, L.J., Petrovic, N., \& Manojlovic, N. (2009). Handbook for parents of young athletes. Belgrade, Serbia: Republic Institute for Sport.

43. Crawford, D.W., Jackson, E.L., \& Godbey, G. (1991). A hierarchical model of leisure constraints. Journal of Leisure Sciences, 13(4), 309-400.

44. Gomez-Lopez, M., Gallegos, A.G., \& Extremera, A.B. (2010). Perceived barriers by university students in the practice of physical activities. Journal of Sport Science and Medicine, 9(3), 374381.

45. Hashim, H.A. (2012). Perceived barriers to recreation sport participation in university students: a comparison between international and local students in the United States. Pertanika Journal of Social Sciences and Humanities, 20(1), 197-203. 